\title{
Androgen Triggers the Pro-Migratory CXCL12/CXCR4 Axis in AR-Positive Breast Cancer Cell Lines: Underlying Mechanism and Possible Implications for the Use of Aromatase Inhibitors in Breast Cancer
}

\author{
Kalliopi Azariadis ${ }^{\mathrm{a}, \mathrm{d}}$ Fotini Kiagiadaki ${ }^{\mathrm{a}}$ Vasiliki Pelekanou ${ }^{\mathrm{a}, \mathrm{e}}$ Vasiliki Bempi ${ }^{\mathrm{a}}$ \\ Kostas Alexakis ${ }^{a} \quad$ Marilena Kampa $^{a} \quad$ Andreas Tsapis $^{a, b, c} \quad$ Elias Castanas ${ }^{a}$ \\ George Notas ${ }^{a}$ \\ aLaboratory of Experimental Endocrinology University of Crete School of Medicine, Heraklion, Crete, \\ Greece; 'INSERM U976, Hôpital Saint Louis, Paris, France, 'University Paris Diderot, Paris, France; \\ dPresent affiliation: Department of Internal Medicine, University Hospital of Larissa, Greece; 'Present \\ affiliation: Department of Pathology, Yale University, New Haven, CT, USA
}

Key Words

Androgen • Androgen Receptor • CXCL12 • NCOA1 • CXCR4 • P53

\begin{abstract}
Background/Aims: Reports regarding the role of androgen in breast cancer $(\mathrm{BC})$ are conflicting. Some studies suggest that androgen could lead to undesirable responses in the presence of certain BC tumor characteristics. We have shown that androgen induces $\mathrm{C}-\mathrm{X}-\mathrm{C}$ motif chemokine 12 (CXCL12) in BC cell lines. Our aim was to identify the mechanisms regulating the phenotypic effects of androgen-induced CXCL12 on Androgen Receptor (AR) positive BC cell lines. Methods: We analyzed the expression of CXCL12 and its receptors with qPCR and ELISA and the role of Nuclear Receptor Coactivator 1 (NCOA1) in this effect. AR effects on the CXCL12 promoter was studied via Chromatin-immunoprecipitation. We also analyzed publically available data from The Cancer Genome Atlas to verify AR-CXCL12 interactions and to identify the effect or Aromatase Inhibitors (AI) therapy on CXCL12 expression and disease progression in AR positive cases. Results: CXCL12 induction occurs only in AR-positive BC cell lines, possibly via an Androgen Response Element, upstream of the CXCL12 promoter. The steroid receptor co-regulator NCOA1 is critical for this effect. Androgen only induced the motility of p53-mutant BC cells T47D cells via upregulation of CXCR4 expression while they had no effect on wild-type p53 MCF-7 cells. Loss of CXCR4 expression and depletion of CXCL12 abolished the effect of androgen in T47D cells while inhibition of p53 expression in MCF-7 cells made them responsive to androgen and increased their motility in the presence to androgen. Patients with estrogen receptor positive $(E R+) / A R+B C$ treated with AIs were at increased risk of disease progression compared to $E R+/ A R+$ non-AI treated and $E R+/ A R-A I$ treated cases. Conclusion: AIs may lead to unfavorable responses in some ER/AR positive BC cases, especially in patients with $A R+$, p53 mutant tumors.

(C) 2017 The Author(s)

George Notas

University of Crete, School of Medicine,

P.O. Box 2208, Heraklion (Greece)

Tel. +302810394556, Fax +302810394581, E-Mail gnotas@uoc.gr
\end{abstract}




\section{Cellular Physiology Cell Physiol Biochem 2017;44:66-84

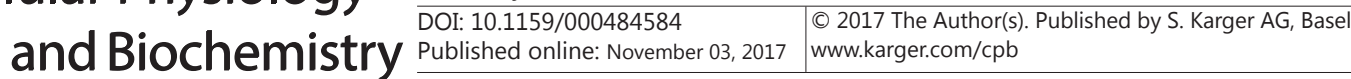 Azariadis et al.: Androgen Induce CXCL12 in AR-Positive Breast Cancer}

\section{Introduction}

Aromatase (CYP19) transforms androgen from the adrenals and the ovaries into estrogen that can induce the growth of estrogen-dependent tumors. This knowledge has led to the use of Aromatase Inhibitors (AIs) as therapeutic agents for breast cancer. AIs are replacing selective estrogen receptor modulators (SERMs) as first-line therapy for estrogen receptor (ER) positive breast cancer, especially in postmenopausal women. However, the fate and the effects of the accumulating androgen in the breast following AI administration are unknown. It is therefore unclear whether, in some cases of breast cancer, local increase of androgen may influence the evolution and outcome of the disease.

Several lines of evidence suggest that androgen might have direct effects on breast cancer cells, by binding to their selective androgen receptors (ARs), present in a large number of breast cancer cases [1]. The exact role of androgen in breast cancer development, prognosis and therapy has been in the center of significant controversies; this is partly due to different applied methodologies, with their focus on different androgen molecules and different groups of patients [2]. Some studies have identified significant correlations between high testosterone levels and breast cancer development in pre-menopausal women. Others have reported low DHEA-S as a risk factor for breast cancer [3-7], while negative studies, unable to correlate androgen levels with breast cancer risk, also exist [8]. Yet, elevated blood androgen levels have been reliably linked to increased breast cancer risk in postmenopausal women $[3,9,10]$. These controversies are also extended to the translational relevance of ARs as a biomarker in breast cancer. Surprisingly, ARs are more frequently present in breast cancer than ERs or PRs [11]. Presence of ARs in ER negative tumors has been related to better disease free survival $[1,12]$ but high AR expression has also been related to an increased likelihood of axillary metastasis [13], implying that AR expression triggers increased tumor capacity to metastasize, at least in lymph nodes. It is to note, however, that our current knowledge of AR expression and identification is limited to the nuclear form of the classical wild-type $\mathrm{AR}$, and does not take into consideration any extranuclear action or isoform of the ARs. Moreover, most of the antibodies currently available for AR detection are polyclonal, limiting the development of companion diagnostics. Finally, AR splice variants like ARV7 have been recently related to a therapeutic failure in castration resistant prostate [14]. These splice variants lack the ligand binding domain but maintain their ability to bind DNA and activate AR-related actions in the prostate. These findings stress the need for further understanding of the role of ARs in breast cancer.

CXCL12 and its receptors CXCR4 and CXCR7 were first recognized in immune cells, regulating cell migration. We now know, through the widespread identification of CXCR4 on different solid tumors, including breast cancer, that this system controls several critical processes, related to primary tumor development and metastatic potential [15]. CXCR4 is essential for breast cancer cell migration to the lung, bone, and lymph nodes, that express CXCL12 [15]. It has therefore been suggested that CXCR4 could be a novel molecular diagnostic and therapeutic target in breast cancer patients [16]. The relation of estrogen and ERs with CXCL12 and CXCR4 in breast cancer cell proliferation and metastatic potential has been examined in depth during the last decade [17-22]. However, only a few reports have investigated the possible interaction between androgen/AR and CXCL12 and its receptors, mostly describing pro-migratory effects in prostate cancer [23-26].

In a previous work, studying the early effect of androgen on gene transcription in breast cancer cells we reported that testosterone triggered the expression of a number of immunerelated genes, including CXCL12 [27]. In this study, we expand the investigation of the effect of androgen on CXCL12 expression in breast cancer cell lines, reporting that they may induce its expression, possibly via a direct binding to an Androgen Response Element (ARE) on the CXCL12 promoter, interacting with $\mathrm{Sp} 1$ sites and having an absolute requirement for the presence of NCOA1. We further report that androgen can induce both CXCL12 and its receptor CXCR4, leading to the increased motility of breast cancer cell lines, depending on the presence of wild type or mutated p53. We also analyze AR and CXCL12 tissue expression 


\section{Cellular Physiology Cell Physiol Biochem 2017;44:66-84

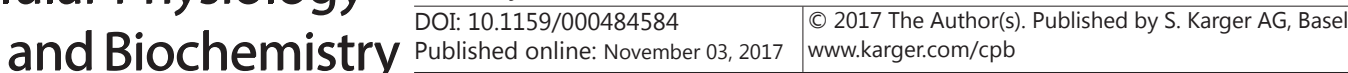

Azariadis et al.: Androgen Induce CXCL12 in AR-Positive Breast Cancer

in several publicly available data series of breast cancer patients. We report that there is a correlation between AR and CXCL12 expression and that AIs increase CXCL12 expression in breast cancer tissue. Finally, we report that in a small patient series, AIs administration in ER positive tumors co-expressing AR, potentially increased the risk of disease progression compared to non-AI treated cases, suggesting that AR and CXCL12 expression could be possible biomarkers for AI administration.

\section{Materials and Methods}

\section{Cell cultures and Chemicals}

The T47D, MCF-7, and MDA-MB-231 cell lines were purchased from DSMZ (Braunschweig, Germany), while SK-BR-3 cells were from ATCC-LGC Standards (Wesel, Germany). T47D, MCF-7, and MDA-MB-231 cells were cultured in RPMI and SK-BR-3 in McCoy's 5A medium, all supplemented with $10 \%$ fetal bovine serum (FBS), at $37{ }^{\circ} \mathrm{C}, 5 \% \mathrm{CO}_{2}$. All media were purchased from Invitrogen (Carlsbad, USA) and all chemicals from Sigma (St. Louis, USA) unless otherwise indicated.

RNA extraction and $q R T-P C R$

Cell lines were serum starved for 24 hours and were then treated with testosterone $\left(10^{-7} \mathrm{M}\right)$ for 3 to 24 hours. Where stated, cyproterone acetate $\left(10^{-6} \mathrm{M}\right)$ was added 1 hour before testosterone. Then cells were lysed to obtain mRNA, using a Nucleospin RNA II isolation kit, (Macherey-Nagel, Duren, Germany). RTPCR and qRT-PCR were performed as described previously [28, 29]. Positive controls were run in parallel with samples. Changes were normalized according to 18S RNA expression. Experiments on individual samples were performed on different days, in duplicates. All primers were selected from qPrimer Depot (qPrimerDepot, http://primerdepot.nci.nih.gov) and synthesized by VBC Biotech (Vienna, Austria). The primers used were: CXCL12 forward-TGG GCT CCT ACT GTA AGG GTT, reverse-TTG ACC CGA AGC TAA AGT GG; CXCR4 forward-AGG TGC TGA AAT CAA CCC AC, reverse-CGT GGA ACG TTT TTC CTG TT; $C X C R 7$ forwardATC CAT CGT TCT GAG GCG, reverse-CTC AGC ACT AAG GGA GCC AG; 18sRNA forward-CTC AGC ACT AAG GGA GCC AG, reverse-CTC AGC ACT AAG GGA GCC AG.

\section{Transfection of breast cancer cells with shRNA or siRNA}

Short hairpin RNA against NCOA1. Short hairpin RNA (shRNA) against NCOA1 was prepared with the use of the psiRNA-h7SKGFPzeo Kit (Invivogen, San Diego, CA), according to the manufacturer's instructions, as described previously [30]. Briefly, the psiRNA-h7SKGFPzeo plasmid was digested with BbsI (New England Biolabs, Ipswitch, MA) and was gel-purified with Extract II columns (Macherey-Nagel, Duren, Germany). The following oligonucleotides were used: NCOA1 oligo1: 5'-ACC TCG CTG AGT CCA AAG ATA ACA AAC TCG -3'; NCOA1 oligo2: 5' - CAA AAA GCT GAG TCC AAA GTA AAC AAA CTC -3'; non-template shRNA oligo-1: 5'ACC TCG GGT ATT TAG GCT ACG ATA GTT CAA GAG ACT ATC GTA GCC TAA ATA CCC TT-3'; non-template shRNA oligo-2: 5'-CAA AAA GGG TAT TTA GGC TAC GAT AGT CTC TTG AAC TAT CGT AGC CTA AAT ACC $\mathrm{CG}-3^{\prime}$. Annealed oligonucleotides $\left(95^{\circ} \mathrm{C}\right.$ for $5 \mathrm{~min}$ and left to cool slowly to $\left.35^{\circ} \mathrm{C}\right)$ were ligated with $\mathrm{T} 4-$ DNA ligase (TAKARA, Otsu, Shiga, Japan) with the digested psiRNA-h7SKGFPzeo plasmid and used for the transformation of LyoComp GT116 cells, plated on Fast-Media Zeo X-Gal plates. After $24 \mathrm{~h}$ incubation at $37^{\circ} \mathrm{C}$, white colonies were picked, and minipreps, positive for the insert, were prepared by incubation of isolated DNA and digested with SpeI. A single positive miniprep for each shRNA was selected for expansion, and the presence of the proper insert was verified by sequencing.

T47D and MCF-7 cells were transfected with the shRNA plasmid using Lipofectamine 2000 according to standard protocols and after 24 hours, zeocin was added to the culture medium. Transfection efficiency was verified by microscopy, by studying GFP positivity ( $>95 \%$ after day 3 ) and by RT-PCR. All mRNA and protein expression experiments were initiated at day 3 post-transfection.

siRNA against TP53 and CXCR4. The oligonucleotides used for the short interfering RNA (siRNA) against TP53 were: oligo1: 5'-AAAAUUCUUUGUUUAGAACAA-3' and oligo2: 5'-GUU CUA AAC AAA GAA UUU UGU-3' while the oligonucleotides used for the siRNA against CXCR4 were oligo1: 5'-AUA UAC AAG AGA UGA AAU CCU-3' and oligo2: 5'-GAU UUC AUC UCU UGU AUA UGA-3'. The oligonucleotides: 5'-GUU AAA UUU CGA AUA UUA CAA-3' and 5'-GUA AUA UUC GAA AUU UGA CGU-3' were used as scrambled siRNA. The oligonucleotides were provided by VBC Biotech (Vienna, Austria). T47D and MCF-7 cells were transfected 


\section{Cellular Physiology Cell Physiol Biochem 2017;44:66-84

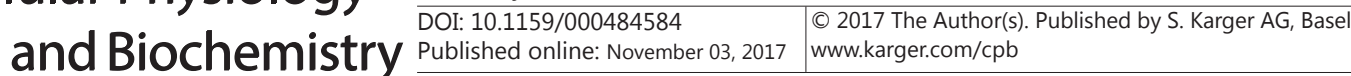

Azariadis et al.: Androgen Induce CXCL12 in AR-Positive Breast Cancer

with the siRNAs using Lipofectamine 2000 according to standard protocols. Experiments were performed 72 hours after transfection. Transfection efficiency was verified by qPCR.

\section{ELISA}

Centrifugation-cleared supernatants from cells, incubated for 24 hours in 24-well plates, were collected for CXCL12 analysis, while the cells were lysed and used for protein determination-normalization. CXCL12 was assayed on supernatant using a commercially available ELISA kit (Abnova ${ }^{\circledR}$ SDF-1alpha Human ELISA kit, Taoyuan City, Taiwan), according to the manufacturer's instructions. The effect of the medium was systematically subtracted. Results are expressed as picograms per milligram of total cellular proteins (measured with the Bradford Assay) per $24 \mathrm{~h}$.

\section{Chromatin Immunoprecipitation}

T47D cells were grown in $75 \mathrm{~cm}^{2}$ flasks and treated with Testosterone $\left(10^{-7} \mathrm{M}\right)$ for $1 \mathrm{~h}$. Cells were treated with $1 \%$ formaldehyde and the cross-linking reaction was stopped by incubation with glycine $0.125 \mathrm{M}$. Cells were then washed with PBS/1mM PMSF, scrapped in the same solution, washed twice and lysed with $2 \mathrm{ml}$ Lysis buffer (1\%SDS/10mM EDTA/50mM Tris (pH 8, 0)/1mM PMSF). Chromatin was sonicated (5 times, 45 sec intervals at 50\% intensity (Vibra Cell sonicator, Sonics \& Materials Co, Danbury, CT, USA), samples were centrifuged (12000rpm, $4^{\circ} \mathrm{C}, 20$ minutes) and the supernatant was aliquoted for further use. Chromatin was then incubated with 1X RIPA buffer, 1mM PMSF, and $5 \mu$ g anti-Androgen Receptor antibody (C-19, sc-815, Santa Cruz, Dallas, TX, USA), or normal rabbit IgG overnight at $4^{\circ} \mathrm{C}$. Sepharose-G beads were preincubated with BSA and salmon sperm, chromatin samples were added and reactions continued for $3 \mathrm{~h}$. After 3 washes, samples were treated overnight with $10 \mathrm{mM}$ TE/20\% SDS $/ 0.1 \mathrm{mg} / \mathrm{ml}$ proteinase K and DNA was isolated with isoamyl alcohol:chloroform. Two sets of primer pairs were designed for qPCR to flank (a) the ARE sequence (forward: 5'-ACT GGG CTT GGA GCC GGG AA-3', reverse: 5'-TGC GCA GGA ATG GAG CTG GC-3', product 224bp) and (b) the Sp1 sites (forward: 5' - CTGA CGG AGA GTG AAA GTG C-3', reverse: 5' - AGA AGG TCA AAG GCC GGA G-3', product 235bp) in the CXCL12 promoter. Primers for the predicted ARE in the Runx2 promoter region (forward: 5'-AGG CAA GCC TCA GAG GGA CAA TTT-3' reverse: 5'GCT ACA GAG ATA AGA AGC CAC ATA CCT CCC-3', product 129bp) were used as further positive controls [31]. ChIP experiments were performed three times. ChIP-qPCR data were normalized with the Percent Input Method. Signals obtained from the ChIP were divided by signals obtained from a 1\% input sample, representing the amount of chromatin used in the ChIP.

\section{Proliferation assay}

T47D and MCF-7 cells were plated at a density of $2 \times 10^{4}$ cells $/ \mathrm{ml}$ in 24 -well plates. They were grown for a total of 6 days, with a change of the medium containing fresh testosterone $\left(10^{-7} \mathrm{M}\right)$ on day 3 . The 6 -day period was chosen in order to be able to assay the effect of testosterone on at least two cell cycles. Growth and viability were measured by a modification of the tetrazolium salt assay [29].

\section{Motility assay}

In vitro scratch motility/migration assay was performed as described previously [32]. Briefly, cells were seeded in six-well plates and allowed to adhere for $24 \mathrm{~h}$. The cells were treated with $10 \mu \mathrm{g} / \mathrm{ml}$ mitomycin C (Sigma) for $3 \mathrm{~h}$ (in order to block the effect of cell proliferation [33]) and washed with PBS. A 1-mm-wide scratch was made across the cell layer using a sterile pipette tip. Fresh, full medium containing testosterone $\left(10^{-7} \mathrm{M}\right)$ was added. All experiments were performed with medium prepared containing the same serum. Photographs were taken every $24 \mathrm{~h}$ at the same position of the scratch.

\section{Boyden dual chamber migration assay}

Cultures were detached with $0.25 \%$ Trypsin-EDTA and $2 \times 10^{4}$ cells were plated in $100 \mu$ l serum free medium on top of the filter membrane in a transwell insert (Corning $®$ Transwell $₫$ polycarbonate membrane inserts, $6.5 \mathrm{~mm}$ with $8.0 \mu \mathrm{m}$ pores). The plate was incubated for 10 minutes at $37^{\circ} \mathrm{C}$ and $5 \% \mathrm{CO}_{2}$ to allow the cells to settle. Next, $600 \mu \mathrm{l}$ of serum supplemented medium (control) or $600 \mu \mathrm{l}$ consisting of $300 \mu \mathrm{l}$ serum supplemented medium and $300 \mu \mathrm{l}$ conditioned medium was added to the bottom chamber. Conditioned medium was prepared from the supernatant of a confluent T47D or MCF-7 cells culture in a $75 \mathrm{~cm}^{2} \mathrm{flask}$ after 48 hours of culture $(10 \mathrm{ml})$. The supernatant was filtered through a $0.2 \mu \mathrm{m}$ syringe filter and half of it 


\section{Cellular Physiology Cell Physiol Biochem 2017;44:66-84

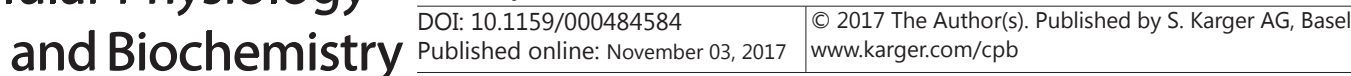 \\ Azariadis et al.: Androgen Induce CXCL12 in AR-Positive Breast Cancer}

was incubated for 30 minutes at RT with shaking with $5 \mu \mathrm{l}$ of an antibody against CXCL12 (Goat anti-human SDF-1 polyclonal antibody, sc-6193) while the other half was incubated with isotype control IgG (normal goat IgG, sc-2028) both from Santa Cruz Biotechnology (Santa Cruz, CA, USA). Five $\mu$ l of isotype IgG was also added in the medium used for the lower chamber of control inserts. After 16 hours, the transwell insert was removed and cells were incubated with $70 \%$ ethanol for 10 minutes and then left to dry. The insert was then incubated with $0.2 \%$ crystal violet at room temperature for 5-10 minutes, washed with distilled water and left to dry. Cells that migrated through the membrane toward the conditioned medium from 10 high power fields were counted and the average number of cells attached to the underside of the membrane were expressed relative to control (scrambled siRNA transfected cells, $600 \mu \mathrm{l}$ of serum supplemented medium in the lower chamber, isotype IgG).

\section{Public microarray data analysis}

Co-expression of AR and CXCL12 was studied in the METABRIC breast cancer data [34, 35] through the online tool cbioportal (http://www.cbioportal.org/) [36, 37].

Furthermore, 1448 TCGA normalized gene expression (based on RNAseq data) cases from 12 different pathologies were downloaded from http://compgenome.org/TCGA/software.html. These cases have been described elsewhere [38]. From these data, 151 breast cancer patients were extracted. AR status was assigned positive or negative based on the retrieval of a positive or negative value after z-transformation. Clinical data of breast cancer cases, including treatment applied, ER, PR, Her2 status, tumor status and disease relapse were retrieved from TCGA by the use of the TCGA assembler software in R [39] v1.0.3 and manually curated to match the Zodiac identified breast cancer cases.

Finally, we extracted data from the GEO-deposited GDS3116 study [40]. In this series of breast cancer patients, microarray analysis was performed on samples obtained before and after 14 days of treatment with letrozole. Normalized matrix data were downloaded from the GEO-dataset site and all probe sets related to the AR, CXCL12, CXCR4, CXCR7, and ESR1 were isolated. In case of multiple probe sets, the maximal value was retained for further analysis.

\section{Statistical analysis}

Statistics were performed with the SPSS v 21.0 (SPSS, Chicago, IL) program. Student's t-test, chi-square, one-way ANOVA were used where appropriate. A statistical threshold of 0.05 was retained for significance.

\section{Results}

Androgen induces CXCL12 gene expression and protein production from androgen receptor (AR) positive breast cancer cell lines

In a previous work [GSE18146, 27], we have reported that T47D and MDA-MB-231 cells express CXCL12 (probe sets 203666_at and 209687_at). In an ongoing work, we have also confirmed the expression of CXCL12 by MCF-7 and SKBR3 cells (Fig. 1A). We have previously reported [GSE18146, 27] that testosterone activated an early (3h) induction of transcripts and subsequently pathways related to cytokine/chemokine signaling and immune-related genes, including CXCL12, in T47D but not in MDA-MB-231 cells. Here, we report that testosterone induces CXCL12 in ER-positive MCF-7 and T47D cells, but not in the SKBR3 or the MDA-MB-231 cell line by qRT-PCR (Fig. 1B). As this differential expression might be related to the presence of active androgen receptors, we studied their expression in these four breast cancer cell lines. As reported in previous studies $[41,42]$ and verified here, AR mRNA was present only in T47D and MCF-7 cells (Fig. 1B inset), suggesting that the increase of CXCL12 by testosterone might be related to the presence of AR in these cell lines.

The implication of AR in the effect of androgen on CXCL12 expression was verified by qPCR for CXCL12, in testosterone $\left(10^{-7} \mathrm{M}\right)$ treated T47D, MCF-7, MDA-MB-231 and SKBR3 cells. Only AR positive breast cancer cell lines MCF-7 and T47D increased the expression of CXCL12 in response to testosterone, while AR negative cell lines MDA-MB-231 and SKBR3 did not show any induction (Fig. 1B). A time-course (3-24 hours) study of CXCL12 expression in response to testosterone of MCF-7 and T47D cells revealed that both cell lines respond 

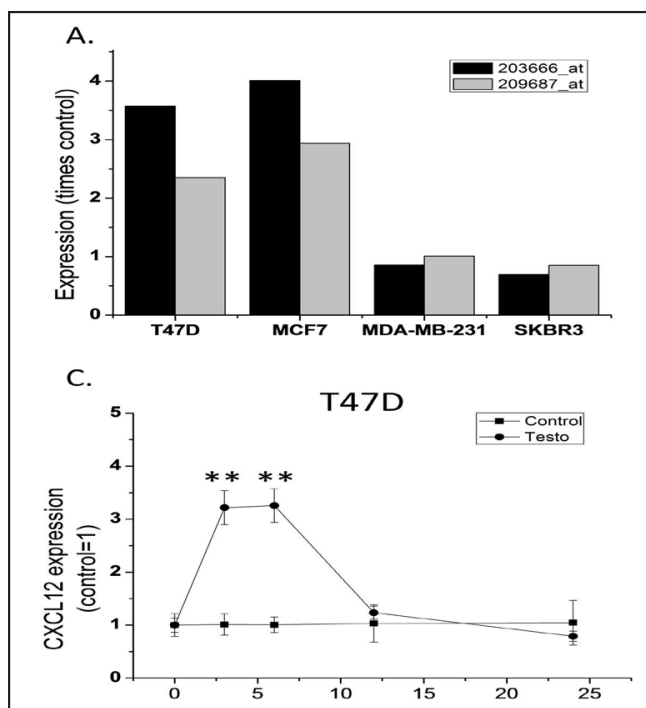

E.

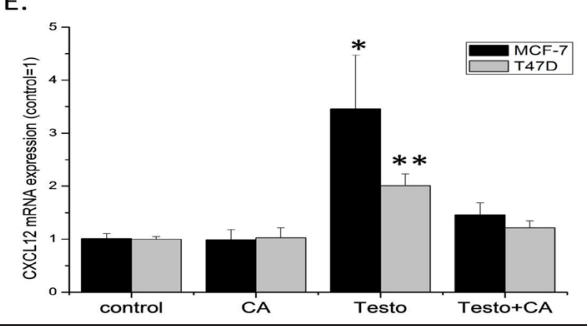

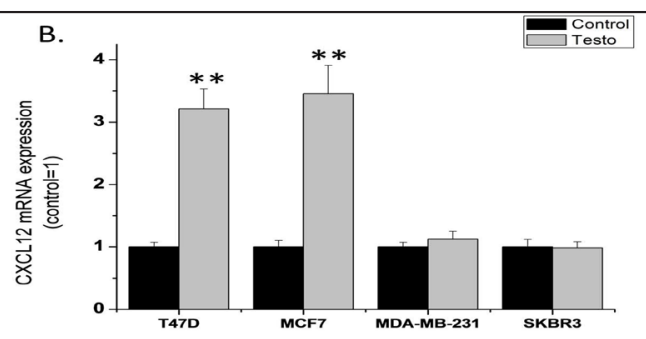

D.

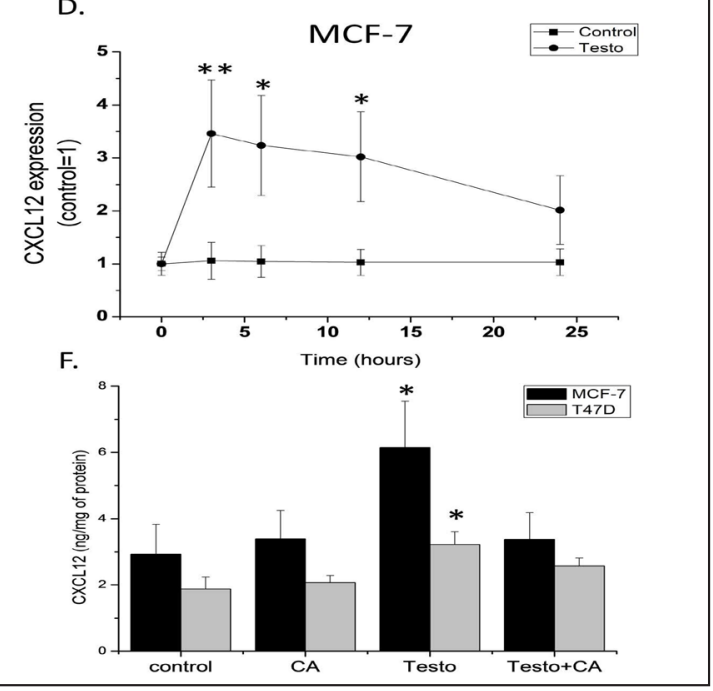

Fig. 1. A. Graphical presentation of transcripts 203666_at and 209687_at, both mapping CXCL12 in Affymetrix U133 plus2 human gene expression array. B. Real-time PCR analysis of CXCL12 expression in breast cancer cell lines verified that only AR positive cell lines increase its expression in response to Testosterone. Inset. RT-PCR for androgen Receptor Expression in T47D, MCF-7, MDA-MB-231 and SKBR3 cells. Only the first two cell lines express AR. All experiments were repeated in three independent duplicates and results were compared with Student's t-test. C and D. Time-course of CXCL12 expression in T47D and MCF-7 cells with qPCR. All experiments were repeated in three independent duplicates and results were compared with ANOVA. E and F. mRNA expression (E) and protein secretion (F) of CXCL12 in T47D and MCF-7 cells. Cells were treated with testosterone $10^{-7} \mathrm{M}$ in the presence or absence of cyproterone acetate (CA, $\left.10^{-6} \mathrm{M}\right)$ for 3 or 24 hours for mRNA and protein studies respectively. Result from three independent experiments (mean $\pm \mathrm{SE}$ ) repeated in duplicates compared with student's t-test $(\mathrm{A}, \mathrm{B}, \mathrm{E}, \mathrm{F})$ and ANOVA (C, D), ${ }^{*} \mathrm{p}<0.05,{ }^{* *}$ $\mathrm{p}<0.01$ vs control or time 0 hours.

by increasing CXCL12 expression. However, MCF-7 cells displayed a sustained increased transcription over time, while T47D cells showed an initial induction at 3 and 6 hours followed by a return towards basal levels at 12 and 24 hours (Fig, 1C and D). Furthermore, the presence of the AR-antagonist cyproterone acetate during treatment resulted in a reversion of testosterone effect on CXCL12 transcription and secretion (Fig. 1E and F respectively), confirming the implication of AR in this phenomenon.

\section{AR activation induces CXCL12 expression via an ARE upstream its promoter in cooperation} with $\mathrm{Sp} 1$ sites within the promoter.

In order to identify whether the effect of androgen on CXCL12 expression is mediated via a direct genomic effect of AR, we examined the promoter of CXCL12 for the presence of an ARE. We identified with the ECR browser (http://ecrbrowser.dcode.org/) a putative ARE at position -1627 to -1613 upstream of the CXCL12 promoter (Fig. 2A). This in silico information was verified with chromatin immunoprecipitation (CHIP) followed by qPCR with specific primers flanking this region, in testosterone-treated T47D cells. Primers targeting a 
Fig. 2. A. graphical presentation of the CXCL12 promoter. The position of the putative Androgen Response Element and of the 4 Sp1 sites in the proximal promoter region are denoted. Arrows present graphically the position of the primers used for the Chromatin Immunoprecipitation assay presented in $\mathrm{B}$. B. Chromatin Immunoprecipitation Assay with qPCR in T47D cells with primers targeting the ARE region of the RUNX gene (control-top), the ARE (middle) and the Sp1 (down) region of the CXCL12 promoter. In testosterone $\left(10^{-7} \mathrm{M}\right)$ treated T47D cells, the

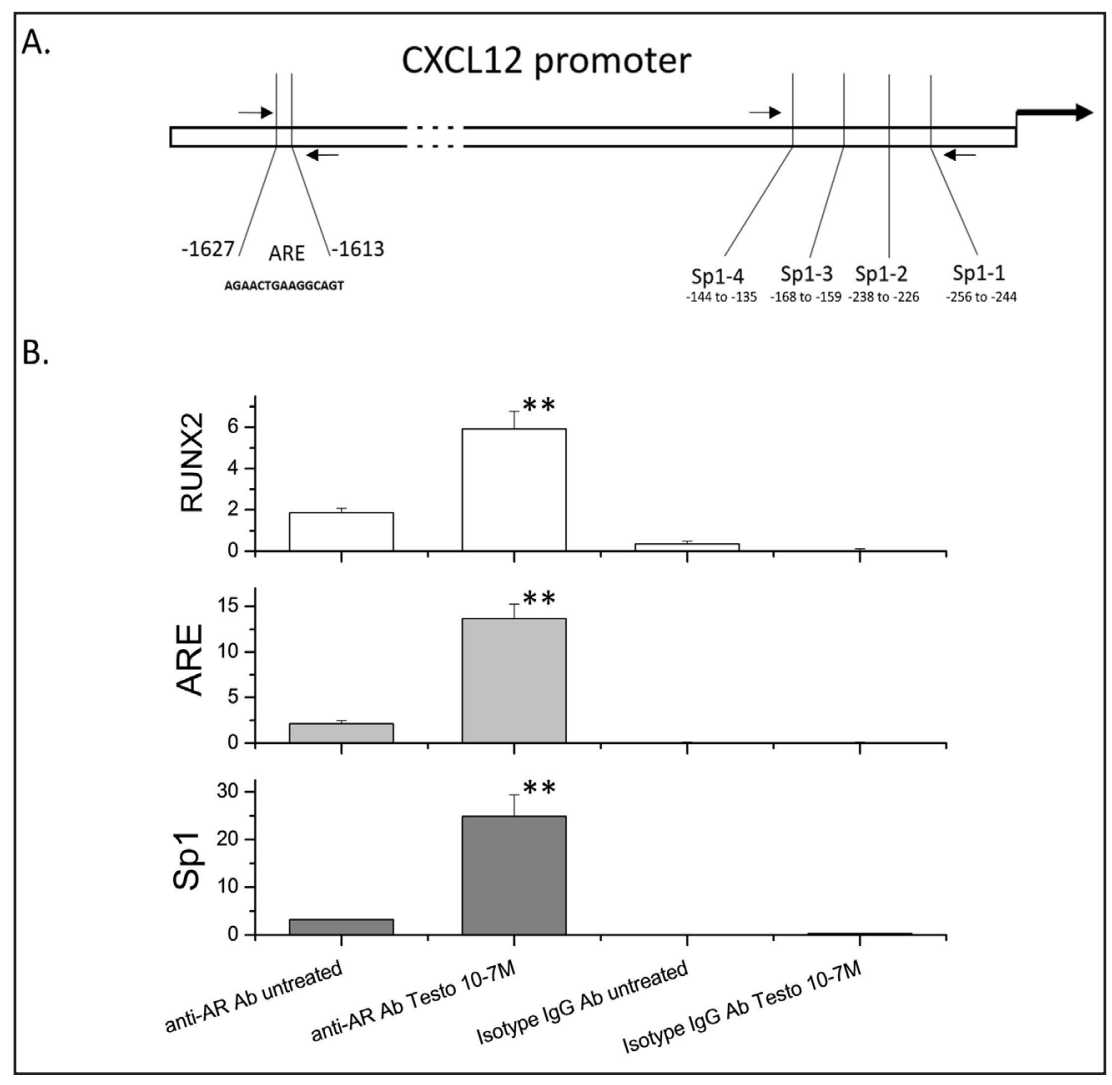
AR was bound to the amplified sequences. Result from three independent experiments (mean \pm SE) compared with student's ttest, ${ }^{* *} \mathrm{p}<0.01$ vs anti-AR antibody untreated cells.

predicted ARE in the Runx2 promoter region (a promoter that has been shown previously to be an AR target [31]) were used as a positive control (Fig. 2B top panel). Our data show that the addition of testosterone results in the precipitation, by the anti-AR antibody, of the DNA sequence that includes the ARE upstream of the CXCL12 promoter (Fig. 2B middle panel), indicating that $\mathrm{AR}$ binds to this sequence and thus that it is a functional ARE.

The in silico analysis of the promoter region of CXCL12 further evidenced the presence of multiple Sp1 binding sites in the proximal region of the promoter (Sp1-1 -144 to -135, Sp1-2 -168 to -159, Sp1-3 -238 to -226 and Sp1-4 -256 to -244). Interaction of AR with Sp1 via DNA loop regulated by coactivators and other transcription factors has been reported previously to be important for the regulation of several genes [43-45]. We, therefore, assayed whether the sequence including the Sp1 sites in the promoter of CXCL12 was co-immunoprecipitated with AR. Again, in testosterone treated cells, chromatin immunoprecipitation was positive for the Sp1 containing sequence of the CXCL12 proximal promoter region (Fig. 2B, lower panel). This suggests that AR induces CXCL12 expression through a direct effect on its promoter, with a concomitant interaction with the proximal sequence of the promoter that contains the Sp1 sites.

\section{NCOA1 is required for the androgen-induced CXCL12 expression}

The DNA binding and transcriptional action of nuclear steroid receptors relays on the recruitment and physical interaction with receptor co-regulators [see 46, for a recent review]. Several such co-regulators have emerged as potential novel pharmaceutical targets, due to their ability to regulate the function of their relevant nuclear receptor, including the androgen receptor [47]. Among them, the family of Steroid/Nuclear receptor coactivator 


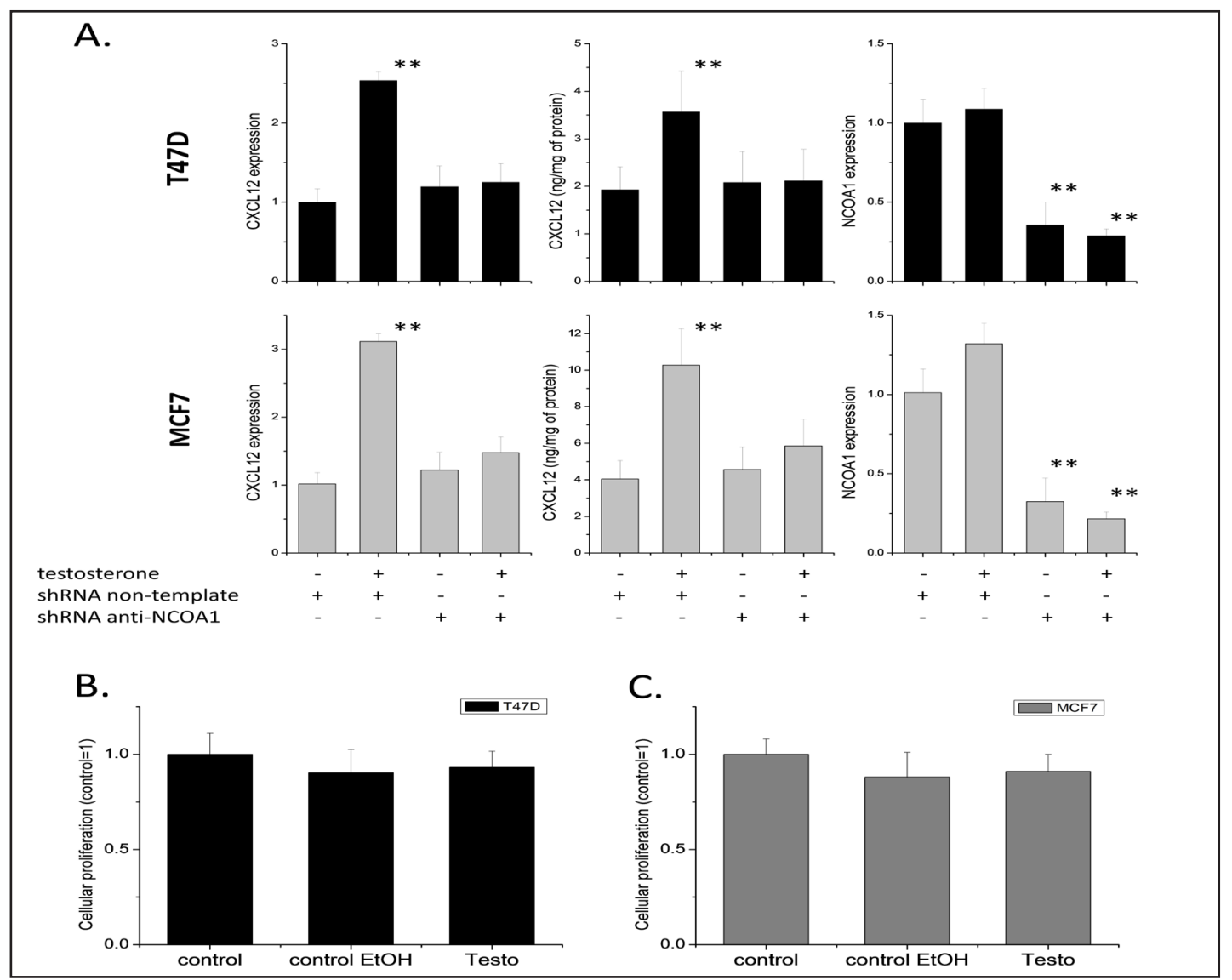

Fig. 3. A. Effect of NCOA1 downregulation on the mRNA expression (left panels) and protein production (middle panels) of CXCL12 in T47D (top) and MCF-7 (bottom) cells. Cells transfected with a non-template plasmid or with a plasmid containing shRNA against NCOA1 were treated with testosterone $10^{-7} \mathrm{M}$ for 3 or 24 hours for mRNA and protein studies respectively. NCOA1 down-regulation was verified with qPCR (right panels). All experiments were repeated in three independent duplicates (mean $\pm \mathrm{SE}$ ) and results were compared with ANOVA ${ }^{* *} \mathrm{p}<0.01$. B and C. Effect of testosterone $\left(10^{-7} \mathrm{M}\right)$ on the proliferation of T47D (B) and MCF-7 (C) cells.

(SRC or NCOA) and especially its first member (NCOA1 or SRC-1) has been reported to mediate estrogen-related CXCL12 enhanced transcription in MCF-7 cells [48], while the role of NCOA2 in breast cancer is less well characterized. We investigated the possible implication of this co-activator on the AR-mediated transcription and translation/secretion of CXCR12 in the two cell lines that responded to androgen. We transfected T47D and MCF-7 cells with a specific shRNA against NCOA1 and then stimulated them with testosterone. We show that non-template RNA transfection had no significant effect on CXCL12 mRNA or protein. However, in both MCF-7 and T47D cells, NCOA1 shRNA reverted completely the effect of testosterone on CXCL12 transcription and protein synthesis/secretion, suggesting that this AR action is an absolute requirement of NCOA1 in order to proceed (Fig. 3A).

The effect of androgen on breast cancer cell lines motility depends on the enhanced expression of CXCL12 and its receptor CXCR4

CXCL12 actions in breast cancer are associated with cell proliferation, cell migration and the formation of breast cancer metastases [15]. Here, in order to investigate whether enhanced CXCL12 expression, under testosterone treatment, is implicated in an increased metastatic potential of MCF-7 and T47D cells, we treated the two cell lines with testosterone and investigated their proliferation and their motility potential. Testosterone had no effect on 


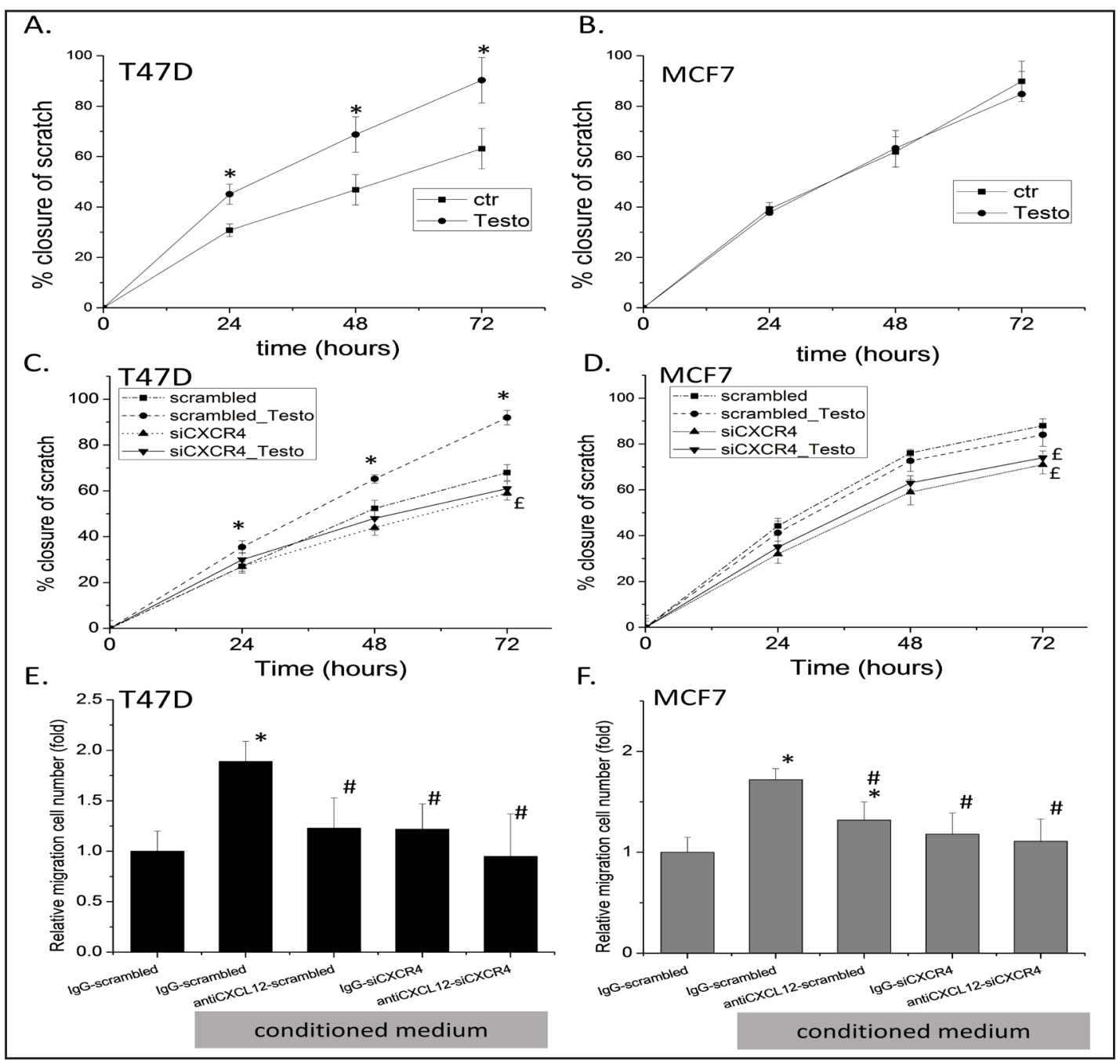

Fig. 4. $\mathrm{A}$ and $\mathrm{B}$. Testosterone $10^{-7} \mathrm{M}$ induced the motility of T47D cells (A) while it had no effect on MCF7 cells (B), a result compatible with the induction of the first and inhibition in the latter of CXCR4. C and D. Inhibition of CXCR4 expression in T47D cells blocked the increased capacity for wound closure in the presence of androgen, while it caused an inhibition of the motility of MCF-7 cells regardless of the presence of testosterone. E and F. Boyden dual chamber migration assay showed that both T47D and MCF7 cells respond to the CXCL12 presence in the lower chamber and that loss of CXCR4 can inhibit their capacity to migrate towards it. All experiments were repeated in at least three independent duplicates (mean $\pm \mathrm{SE}$ ) and results were compared with ANOVA, ${ }^{*} \mathrm{p}<0.05$ and ${ }^{* *} \mathrm{p}<0.01$ vs control, $€ \mathrm{p}<0.01$ vs respective scrambled siRNA treated cells, \# $<<0.01$ vs cells transfected with scrambled siRNA assayed in the presence of isotype IgG treated conditioned medium.

the proliferation of both T47D and MCF-7 cells (Fig. 3B and 3C). In the wound repair/scratch assay, our data show that testosterone, as expected [49], increased the motility of T47D cells (Fig. 4A). Unexpectedly, however, testosterone did not have any effect on the motility of MCF7 cells (Fig. 4B), in spite of the increased and sustained expression of CXCL12 (see Fig. 1D).

In different systems, including breast cancer [17-22], it has been reported that CXCL12 can act in an autocrine manner, through its two cognitive receptors CXCR4 and CXCR7. Previous work has shown that estrogen induces both CXCL12 and its receptor CXCR4 in breast cancer and this mechanism is critical for their pro-proliferative and pro-migratory effect in breast cancer [17-22]. In order to investigate whether the differential effect of androgen on T47D and MCF-7 cells motility relies on differences in the expression of the CXCL12 receptors, we 
Fig. 5. Effect of testosterone $\left(10^{-7} \mathrm{M}\right)$ on the expression of CXCR4 and CXCR7 in T47D (A) and MCF-7 (B) cells. Effect of p53 inhibition on the induction of CXCR4 expression by testosterone in T47D (C) and MCF-7 cells (D). Effect of p53 inhibition on the motility of T47D (E) and MCF-7 (F) cells in response to testosterone. All experiments were repeated in three independent triplicates and results were compared with Student's t-test. ${ }^{*} \mathrm{p}<0.05, * *$ $\mathrm{p}<0.01$ and $* * * \mathrm{p}<0.0001$ vs respective control, \# $\mathrm{p}<0.01$ vs scrambled siRNA transfected untreated cells, \& p $<0.01$ vs siTP53 transfected untreated cells.
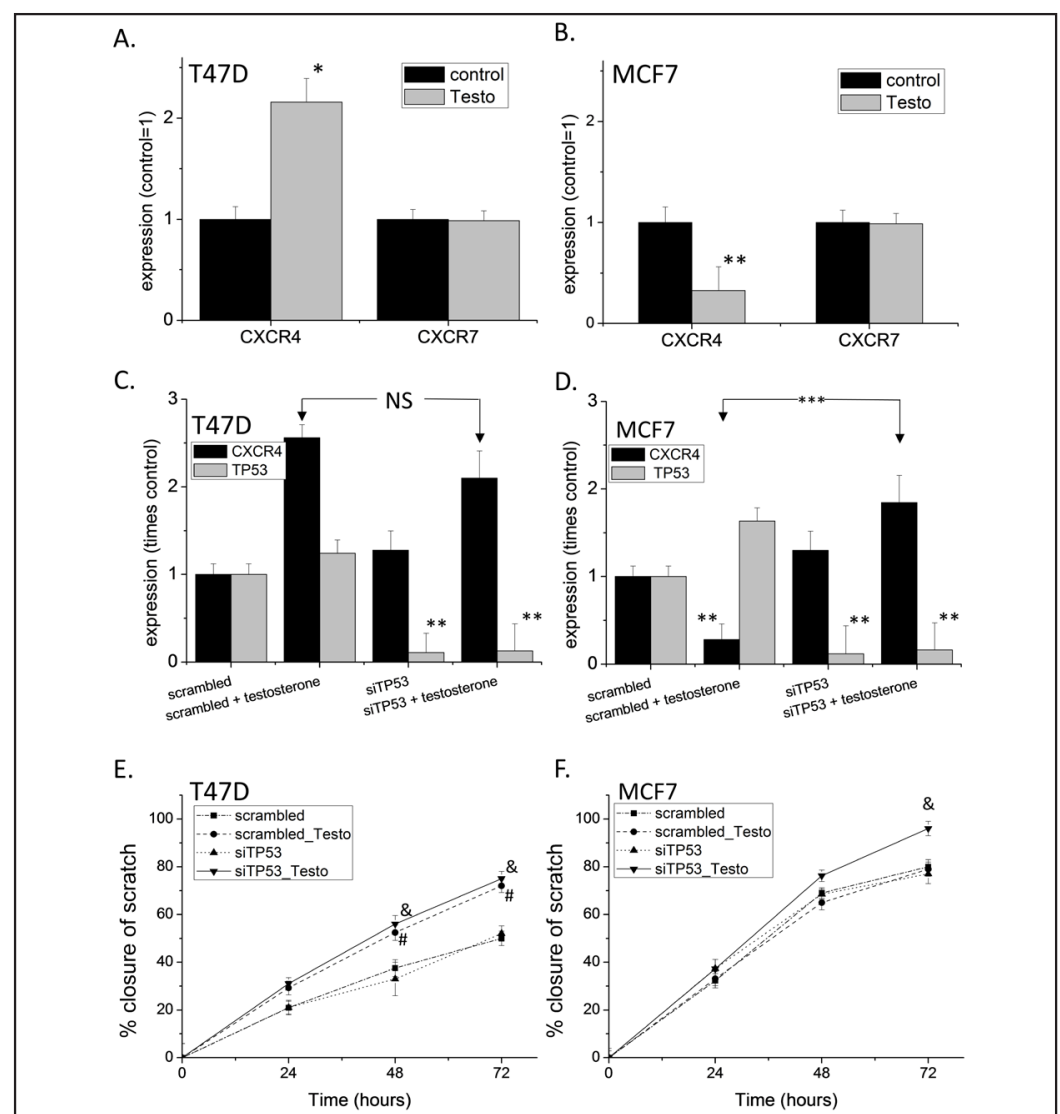

measured by qRT-PCR their expression profile in cells treated with testosterone (Fig. $5 \mathrm{~A}$ and B). No effect of testosterone was observed in CXCR7 expression. Contrariwise, testosterone induced the expression of CXCR4 in T47D cells, while it inhibited its expression in MCF-7 cells. It should be noted that MCF-7 cells express $40 \%$ more CXCR4 compared to T47D cells. siRNA inhibition of CXCR4 (Fig. 6A), blocked the effect of testosterone on cellular migration in T47D cells (Fig. 4C), while in MCF-7 cells, it caused a slight inhibition of cell migration that was independent of testosterone (Fig. 4D).

This critical role of the CXCL12/CXCR4 system in cell migration was further verified with Boyden dual chamber migration assay (Fig. 4E and F). The presence of CXCL12 in the conditioned medium of T47D or MCF-7 cells significantly increased cell migration. This increased migration was inhibited by either by antiCXCR4 siRNA transfection or by CXCL12 protein depletion of the medium by a neutralizing antibody against CXCL12. As expected, the effect of both inhibitory mechanisms was not additive.

The fact that CXCR4 displays such a different response to androgen in these two cell lines suggests that the regulation of its expression is under the control of more complicated mechanisms that are dependent on the intracellular machinery of each cell line. One of them could be p53 status which is unaltered in MCF-7 and mutated in T47D cells $[50,51]$. In a previous study, it was reported that in MCF-7 breast cancer cells CXCR4 expression is under the negative feedback control of the non-mutated form of p53 [50]. Here we verified that inhibition of wild-type p53 expression in MCF7 cells by siRNA results in an enhanced expression of CXCR4 (Fig. 5D). In addition, p53 expression inhibition reverted the inhibitory effect of testosterone on CXCR4 expression. In T47D cells bearing a non-functional p53 mutation [52,53] the expression of CXCR4 showed a slight reduction after p53 inhibition that was not significant but is in accordance with the finding that dominant negative and cancer-specific p53 mutants can induce CXCR4 expression [50]. Hence, loss of p53 expression 


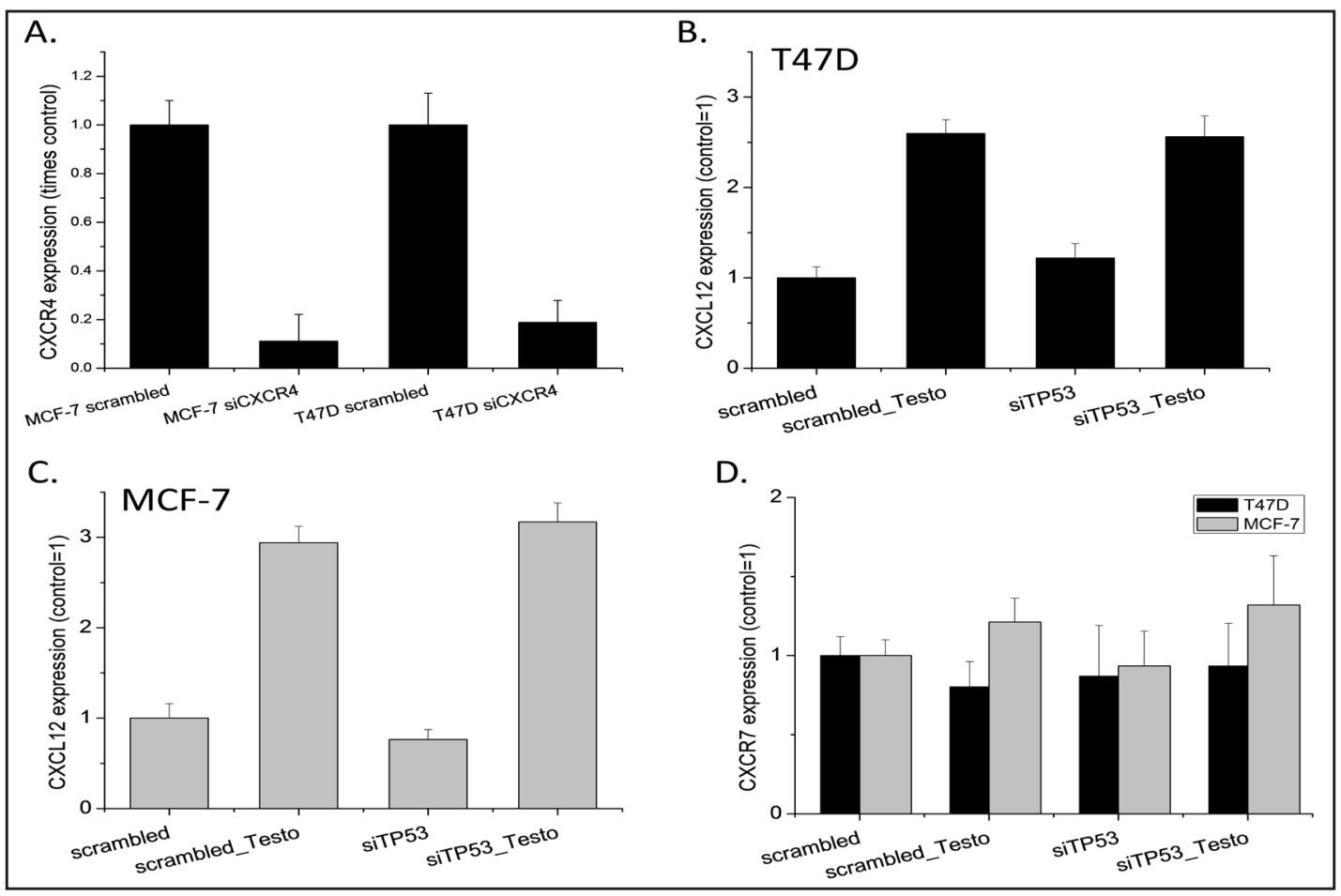

Fig. 6. A. Verification of siRNA induced CXCR4 silencing. B. Effect of p53 silencing on the expression of CXCL12 in T47D cells. C. effect of p53 silencing on the expression of CXCL12 in MCF-7 cells. D. Effect of p53 silencing on the expression of CXCR7 in T47D and MCF-7.

and the subsequent increased expression of CXCR4 might induce an increased migratory capacity of MCF7 cells. Indeed, when we repeated the motility assays using anti-TP53 siRNA treated MCF7 cells, we found that testosterone induced an increased migratory capacity. In contrast, no effect of TP53 inhibition was observed in T47D (Fig. 5E and F). It is to note that p53 inhibition had no effect on CXCL12 and CXCR7 expression in both cell lines (Fig. 6 B, C, and D).

AR expression is correlated with CXCL12 expression in breast cancer and AI therapy in ER / $A R$ positive tumors is related to increased CXCL12 expression and increased recurrence compared to non-AI treated ER $\alpha$ positive cases

Our in vitro data show that AR stimulation by testosterone increases CXCL12 expression and secretion together with CXCR4 expression, in a NCOA1 and p53-related manner, and this enhancement of expression increases cell migration. In order to investigate whether a similar situation occurs in vivo, we investigated the expression of CXCL12 and its relation to AR expression in several publicly available datasets.

We first analyzed data from the 2509 breast cancer cases of the METABRIC study [34, 35 ] and found a clear correlation between the expression of AR and CXCL12 ( $<<0.001)$. We then analyzed data from a series of 52 ER positive breast cancer patients that received 2 doses of the AI letrozole before surgical removal of their cancers [40], since in this setting positivity for AR is expected to be more than $90 \%$. Thirty-seven of these patients displayed an increase in CXCL12 expression compared to 15 that displayed a decrease. Overall there was a $44 \%$ increase in the expression of CXCL12 in the tissue samples obtained before and after treatment (paired t-test, $\mathrm{p}=0.0012$ ). These results are in accordance with our findings regarding the induction of CXCL12 by androgen.

In another approach we used the web-resource zodiac (http://compgenome.org/ zodiac) [38], integrating and analyzing genomic and proteomic data of 1448 cases of 11 malignant pathologies, including 151 cases of breast cancer. As shown in Fig. 7A, in the 


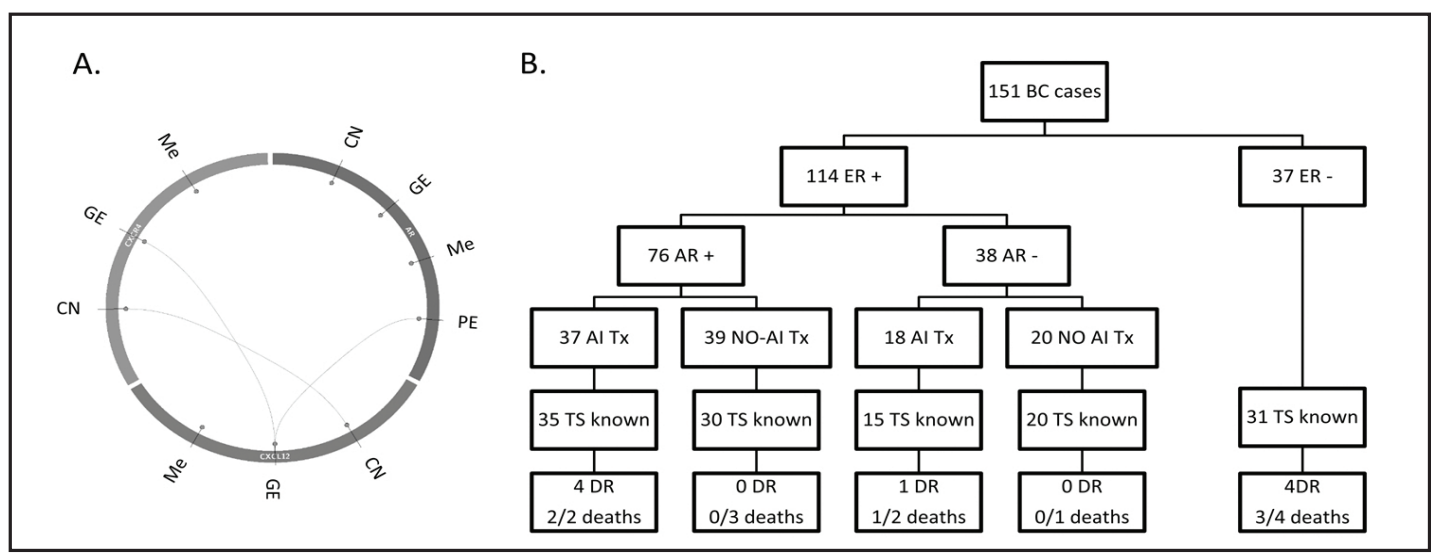

Fig. 7. A. The interaction between AR, CXCL12 and CXCR4 Gene Expression (GE), Copy Numbers (CN), Methylation (Me) and Protein Expression (PE), derived from the analysis of 1448 TCGA cases with the use of the Zodiac software as described in the Material and Methods section [38, 39]. B. Flowchart of the analysis of the 151 Cancer Genome Atlas breast cancer cases. AI treated ER+/AR+ cases displayed similar relapse rate with ER- cases. ER: estrogen receptor status, AR androgen receptor status, Tx: therapy, TS: tumor status, DR: Disease Relapse. Deaths in the lowest boxes are noted as breast cancer relapse related in the numerator and total in the denominator.

whole cohort of patients ( $\mathrm{n}=1448)$, CXCL12 and CXCR4 expression are positively correlated $(\beta=4.75, \mathrm{FDR}<0.0001)$ and additionally AR protein expression is positively correlated with CXCL12 gene expression $(\beta=4.92, \mathrm{FDR}<0.0001)$, verifying our in vitro data and extending them to pathologies beyond breast cancer.

Finally, we downloaded transcription and proteomic data from the Zodiac site and extracted normalized data values only for the breast cancer patients $(n=151)$, together with their clinical data, as described in Material and Methods. Analysis of these 151 cases identified $37 \mathrm{ER}+/ \mathrm{AR}+$ and $18 \mathrm{ER}+/ \mathrm{AR}$ - cases that received AI therapy, alone or in combination with SERMs and/or chemotherapy. Analysis of the cases with known tumor status (Fig. 7B) revealed that in the AR+ cases there were 4 disease recurrences ( 2 cancer-related deaths, both in the disease recurrence cases) in the AI treated group and 0 recurrences ( 3 cancer unrelated deaths) in the AI non-treated group (one tailed chi square $\mathrm{p}=0.028$ ). In the ARcases there was only 1 recurrence ( 2 deaths, only one related to disease recurrence) in the AI treated group and 0 recurrences ( 1 cancer unrelated death) in the AI non-treated group. Finally, in the 31 ER- cases that tumor status was known there were 3 recurrences ( 4 deaths, 3 of them in the recurrences). Although data are limited and further investigations are required, disease recurrence in the $\mathrm{ER}+\mathrm{AR}+\mathrm{AI}$ treated group appears to be similar to that of the ER- group (22 out of 31 of whom where Triple Negative Breast Cancer cases (TNBC)), that is well known for its worse prognosis. This effect was not observed in AR negative AI treated cases.

\section{Discussion}

In spite of the tremendous progress in our understanding of the cellular and molecular biology of breast cancer and the widespread use of anti-hormonal (SERMs, aromatase inhibitors), chemotherapy and personalized biological therapy, its incidence rate remains relatively stable $(0.1 \%$ increase between $2003-2012)$, while its mortality decreased only by $1.9 \%$ over the same period [54]. This rather alarming result reveals our still incomplete understanding of breast cancer biology, especially in cases that fail treatment, and the need for further research that can translate into more effective therapies. The present study subscribes in this direction, by reporting a direct effect of androgen, through functional androgen receptors, on the production and secretion of CXCL12 and its receptor CXCR4 by 
breast cancer cells. We further describe that the underlying mechanism of this effect possibly includes AR binding on an ARE element upstream of the CXCL12 promoter, interaction with Sp1 elements and the absolute requirement of NCOA1. This CXCL12/CXCR4 enhancement leads to the increased motility of breast cancer cells. Translating these elements to a clinical context, we provide a limited clinical proof of principle from a group of AI treated patients. Although it is clear that further clinical data analysis is required, it is possible that there is a group of breast cancer patients with AR-positive breast tumors where AIs may have an undesirable effect.

CXCL12 and its receptors CXCR4 and CXCR7 are major elements implicated in breast cancer development and metastasis $[15,16]$. In ER positive tumors, estrogen induces enhanced CXCL12/CXCR4\&7 production/secretion, leading to cellular proliferation and tumor invasion/metastasis [17-22]. However, the interaction of androgen with the CXCL12/ CXCR4/CXCR7 system in the breast had not been studied until now. Androgen has been implicated in the regulation of breast cancer cell proliferation [55] and data from prostate cancer show that androgen modulates CXCR4 and stimulate cellular migration $[23,26]$, a result we extend to breast cancer in this investigation. In addition, castrated male rats have lower CXCL12 levels compared to control rats and after induced myocardial infarction, they display reduced ability to recruit $\mathrm{CD}_{3} 4^{+}$bone marrow cells to ischemic areas of the myocardium [25]. Our data of direct androgen effects on CXCL12 expression provide a molecular mechanism that explains this finding. We also report that, similarly to estrogen, NCOA1 is essential for the effective induction of CXCL12 by androgen [48]. Interestingly enough NCOA1 is also overexpressed in aromatase inhibitor resistant breast tumors [56]. Finally, our findings suggest that CXCL12 may belong to the list of genes that display interaction of a distal AR/ARE site with several proximal Sp1 sites in their promoter regions along with the genes of Cyclin-Dependent Kinase Inhibitor p21 [43], Monoamine oxidase A [44] and the mouse vas deferens protein (MVDP) [45].

Our findings suggest that androgen (circulating or locally produced/accumulated) may have an unfavorable effect in some breast cancer patients, mainly through a pro-metastatic action. A prerequisite for this would be the expression in these cases of CXCL12 receptors CXCR4 and/or CXCR7. To our surprise, androgen could induce CXCR4 expression only in T47D cells while they inhibited its expression in MCF-7 cells, leading to a clear phenotypic difference, with T47D cells having increased motility in response to androgen in contrast to MCF-7 cells, which remain insensitive to androgen treatment. One of the major differences between these cell lines is their different p53 status with MCF-7 bearing the intact, while T47D cells expressing mutant p53 (http://p53.free.fr/Database/Cancer_cell_lines/p53_ cell_lines.html), although whether mutant p53 in these cells is dominant-negative or has distinct pro-survival effects is still under investigation [57]. Wild-type p53 has been found to suppress CXCR4 expression in MCF-7 cells [50]. Our finding of reversal of CXCR4 inhibition by androgen in this cell line, cells via the inhibition of p53, is in accordance with this previous result. Furthermore, the fact that p53 loss or non-functional mutation can revert action on CXCR4 expression from inhibitory to stimulatory has been reported previously in MCF-7 cells that were transfected with dominant-negative V143A p53 mutant or cancer-specific p53 mutants, R175H or R280K [50]. Our expression results and the specific stimulatory effect of testosterone on CXCR4 expression after p53 inhibition were also in accordance with our motility studies, with MCF7 cells becoming responsive to testosterone once p53 expression was blocked. Therefore, a non-functional p53 may be an important element regulating the response of breast cancer cells to increased androgen in the tumor microenvironment.

Another question raised by our findings is whether androgen has a direct effect on CXCR4 expression. Our data suggest that the effect of androgen on CXCR4 is indirect. Although we identified an ARE in the CXCR4 promoter region (data not shown) the fact that a functional p53 is pivotal for the inhibitory effect of androgen on CXCR4 expression suggests a more complicated series of events. Some of the possible mechanisms could include (a) a direct inhibitory effect of AR on the CXCR4 promoter that is mediated via a tethered interaction with p53 (b) an inhibitory effect mediated by a wild-type p53 effect

\section{KARGER}




\section{Cellular Physiology Cell Physiol Biochem 2017;44:66-84

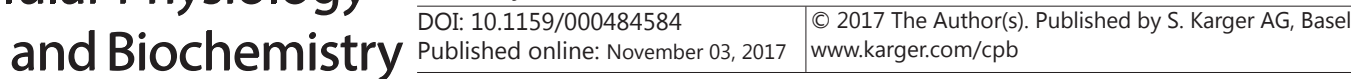 \\ Azariadis et al.: Androgen Induce CXCL12 in AR-Positive Breast Cancer}

on the CXCR4 promoter with or without a tethered interaction with AR (c) a p53 mediated activation of a signaling pathway that mediates this inhibitory effect (d) an AR mediated activation of a signaling pathway that mediates this inhibitory effect etc. Furthermore, the protein levels and the activation status of other nuclear steroid receptors such as AR, ER $\alpha$, $\mathrm{ER} \beta, \mathrm{PR}$, other transcription factors/protein kinases and coregulators may also be involved. Further studies in the CXCR4 promoter region will help clarify these events.

The role of androgen in the breast remains controversial. In in vitro studies and animal models, androgen was found to be antiproliferative and pro-apoptotic [6], while other studies suggest the development of an aggressive pro-proliferative phenotype [58] depending on the cell type, androgenic agents administered and the type of the receptor protein involved (nuclear, extranuclear/membrane). Opposing proliferative responses of human breast cancer cell lines to androgen suggest that this action may not be solely mediated by binding to classical AR [59]. It has also been suggested that estrogen play a permissive role in androgen actions, since in their presence in culture media, DHEAS and androstenediol have antiproliferative effects in breast cancer, while in their absence the same molecules stimulate growth, an effect not observed with testosterone or DHT, that both inhibit cell proliferation independently of the presence of estrogen [60]. Most importantly, we have previously shown in T47D cells, that this effect is also dependent on non-genomic, membrane-initiated actions of androgen, triggering specific signaling cascades [61] since it can be reproduced with the use of membrane-impermeable BSA bound testosterone [62]. Therefore, the results of the in vitro androgen studies in the breast are highly dependent on the cell lines used, their ER status, the type/dose of the androgen used and factors yet unknown, due to our limited understanding of the mechanisms utilized by androgen in order to induce their effects.

ARs have been reported to be present in about $90 \%$ of ER+ tumors, $60 \%$ of ER-/HER2+ tumors and $20-40 \%$ of TNBCs $[12,63]$. Regarding the role of AR expression on the clinical biology of breast cancer, reports have failed to identify a constant pattern: AR expression in ER negative breast cancer has been linked to increased disease free survival [1], but high AR expression in unselected breast cancer cases has been correlated to increased (axillary) metastasis [13]. AR positivity has been associated with better outcomes in ER+ breast cancer, possibly because it suggests a more well-differentiated state [64]. Other studies implicate AR expression to ER resistance, as AR overexpression induces SERM and AI resistance in ER positive cells, suggesting that patients with such tumors could benefit from combined antiER and anti-AR therapy [65]. Especially in TNBC, a recent meta-analysis of thirteen studies with 2826 patients reported that AR+ patients had lower tumor grade and more lymph node metastases, while AR positivity was related to prolonged disease free survival, but had no effect on overall survival [12]. Therefore, until now, we are far from understanding the role of AR in breast cancer.

Long before anti-estrogen and anti-HER2 were available and before the existence of studies regarding the expression of ARs in breast cancer, it was suggested that androgen may serve as molecules counteracting estrogen actions in breast cancer, in a yin-yang manner [66]. Testosterone was thus tested as a therapy for unselected breast cancer patients with response rates reported being around 20-25\% [63,67]. These treatments never gained momentum and were quickly abandoned, especially when tamoxifen, the archetype of SERMs, proved to be effective in ER+ breast cancer. Apart from this initial use of androgen in the mid-twentieth century, only small clinical studies can be found in the literature. The anabolic androgen fluoxymesterone has been reported to increase tamoxifen remission rates from $15 \%$ to $38 \%$ in advanced ER+ breast cancer [68], while testosterone propionate led to $17 \%$ disease remission and $41.5 \%$ disease stabilization in patients with metastatic breast cancer, refractory to hormone treatment [69]. Clinical trials that are currently under way, and have focused on non-steroidal anti-androgen (enzalutamide, bicalutamide, darolutamide), selective androgen receptor modulators (Enobosarm), or anabolic steroid (Fluoxymesterone, CR1447) therapy in AR positive breast cancer cases, will probably shed more light in this field (data from www.clinicaltrials.gov). Interestingly, although most studies involve antiandrogen therapy in TNBC and metastatic breast cancer, androgen 
anabolic treatments are also being studied in TNBC, but also in ER positive breast cancer cases, as well as in metastatic cases. Our work provides another element of androgen action in the breast, namely the enhanced production/secretion of the chemoattractant chemokine CXCL12 and the autocrine stimulation of its receptor CXCR4, through the activation of AR, findings that could be of value in the analysis of the abovementioned studies or in the design of new ones.

Our analysis of the public GDS3116 study and TCGA data shows that AR status could modify the effectiveness of AI therapy in breast cancer. AIs block the conversion of androgen to estrogen, thus increasing free testosterone and DHEA-S [70]. Previous studies have shown that patients with ER positive tumors that are responders to neoadjuvant AI therapy, display decreased AR mRNA and nuclear protein, while non-responders continue to have elevated AR expression $[71,72]$. Our data are in accordance with previous reports that AR overexpression in breast cancer cell lines leads to tamoxifen and AI resistance [65, 73]. On a molecular basis, it has been shown that ER activation induces AR DNA binding in sites enriched for estrogen response elements, suggesting a collaboration of the two receptors when both of them are present in the nucleus [74]. Thus, inhibition of AR nuclear localization decreases E2induced tumor growth of ER+/AR+ cell lines [74]. Therefore, increased AR expression may have unfavorable effects in AI treated patients and anti-androgen therapies may benefit a subgroup of AR positive patients. The opposite approach, androgen therapy in breast cancer has already been studied before as stated above and the combination of androgen and antiestrogen as a potential strategy is a concept that has been also discussed in the literature. There seems to be a missing key, possibly a molecular signature that defines the pro- or antioncogenic response of breast cancer cells to androgen. A phase II study (NCT02000375) investigating the safety and activity of a combination of DHEA and an aromatase inhibitor in pre-treated ER+/AR+ postmenopausal patients was terminated early, before reaching its recruitment target, but its data have not been reported.

Personalized therapy for breast cancer has always been an important target since such therapies can be less toxic and more effective than chemotherapy. It relays on the precise measurement of a number of biological markers/elements of the tumor, in order to identify the optimal combination of drugs, beneficial for an individual patient. Our data show that, in this context, measurement of AR expression and p53 mutations as well as a CXCL12/ CXCR4 presence on tumor cells, may be important biomarkers before the clinical decision for aromatase inhibitor administration is made. Although the retrospective character of our clinical data and the small number of patients with recurrence in this cohort are significant limitations of this study, our results suggest that more extensive investigations, directly addressing this issue should be performed, since they could identify a subgroup of ER positive breast cancer patients that may not benefit from AI therapy.

\section{Abbreviations}

AI (Aromatase Inhibitors); SERM (selective estrogen receptor modulator); ER (estrogen receptor); CXCL12 (C-X-C motif chemokine 12); CXCR4 (C-X-C chemokine receptor type 4); CXCR7 (C-X-C chemokine receptor type 7); AR (androgen receptor); TCGA (The Cancer Genome Atlas); NCOA1 (Nuclear Receptor Coactivator 1); ARE (Androgen Response Element); CHIP (chromatin immunoprecipitation); TNBC (Triple Negative Breast Cancer); DHEAS (dehydroepiandrosterone sulfate); HER2 (human epidermal growth factor receptor 2).

\section{Acknowledgements}

This work was supported by the European Union Programs Regional Potential/ Translational Potential Grant 285948 (to GN and EC) and by the University of Crete Special account for Research grant No 3505 (to GN) and by the European Union-FP7 Marie Curie Actions-Career Reintegration Grants PCIG-GA-2011-303723 (to VP). 


\section{Cellular Physiology Cell Physiol Biochem 2017;44:66-84 \begin{tabular}{l|l|l} 
and Biochemistry $\begin{array}{l}\text { DOI: 10.1159/000484584 } \\
\text { Published online: November 03, } 2017\end{array}$ & $\begin{array}{l}\text { (c) } 2017 \text { The Author(s). Published by S. Karger AG, Basel } \\
\text { www.karger.com/cpb }\end{array}$
\end{tabular} \\ Azariadis et al.: Androgen Induce CXCL12 in AR-Positive Breast Cancer}

\section{Disclosure Statement}

All authors declare that they have no conflict of interests.

\section{References}

$>1$ Agoff SN, Swanson PE, Linden H, Hawes SE, Lawton TJ: Androgen receptor expression in estrogen receptornegative breast cancer. Immunohistochemical, clinical, and prognostic associations. Am J Clin Pathol 2003;120:725-731.

-2 Nicolas Diaz-Chico B, German Rodriguez F, Gonzalez A, Ramirez R, Bilbao C, Cabrera de Leon A, Aguirre Jaime A, Chirino R, Navarro D, Diaz-Chico JC: Androgens and androgen receptors in breast cancer. J Steroid Biochem Mol Biol 2007;105:1-15.

-3 Kaaks R, Rinaldi S, Key TJ, Berrino F, Peeters PH, Biessy C, Dossus L, Lukanova A, Bingham S, Khaw KT, Allen NE, Bueno-de-Mesquita HB, van Gils CH, Grobbee D, Boeing H, Lahmann PH, Nagel G, Chang-Claude J, Clavel-Chapelon F, Fournier A, Thiebaut A, Gonzalez CA, Quiros JR, Tormo MJ, Ardanaz E, Amiano P, Krogh V, Palli D, Panico S, Tumino R, Vineis P, Trichopoulou A, Kalapothaki V, Trichopoulos D, Ferrari P, Norat T, Saracci R, Riboli E: Postmenopausal serum androgens, oestrogens and breast cancer risk: the European prospective investigation into cancer and nutrition. Endocr Relat Cancer 2005;12:1071-1082.

4 Secreto G, Toniolo P, Berrino F, Recchione C, Cavalleri A, Pisani P, Totis A, Fariselli G, Di Pietro S: Serum and urinary androgens and risk of breast cancer in postmenopausal women. Cancer Res 1991;51:2572-2576.

5 Secreto G, Toniolo P, Pisani P, Recchione C, Cavalleri A, Fariselli G, Totis A, Di Pietro S, Berrino F: Androgens and breast cancer in premenopausal women. Cancer Res 1989;49:471-476.

6 Somboonporn W, Davis SR, National H, Medical Research C: Testosterone effects on the breast: implications for testosterone therapy for women. Endocr Rev 2004;25:374-388.

$\rightarrow 7$ Key T, Appleby P, Barnes I, Reeves G, Endogenous H, Breast Cancer Collaborative G: Endogenous sex hormones and breast cancer in postmenopausal women: reanalysis of nine prospective studies. J Natl Cancer Inst 2002;94:606-616.

-8 Tworoger SS, Missmer SA, Eliassen AH, Spiegelman D, Folkerd E, Dowsett M, Barbieri RL, Hankinson SE: The association of plasma DHEA and DHEA sulfate with breast cancer risk in predominantly premenopausal women. Cancer Epidemiol Biomarkers Prev 2006;15:967-971.

-9 Wang DY, Allen DS, De Stavola BL, Fentiman IS, Brussen J, Bulbrook RD, Thomas BS, Hayward JL, Reed MJ: Urinary androgens and breast cancer risk: results from a long-term prospective study based in Guernsey. Br J Cancer 2000;82:1577-1584.

10 Zeleniuch-Jacquotte A, Gu Y, Shore RE, Koenig KL, Arslan AA, Kato I, Rinaldi S, Kaaks R, Toniolo P: Postmenopausal levels of sex hormones and risk of breast carcinoma in situ: results of a prospective study. Int J Cancer 2005;114:323-327.

-11 Collins LC, Cole KS, Marotti JD, Hu R, Schnitt SJ, Tamimi RM: Androgen receptor expression in breast cancer in relation to molecular phenotype: results from the Nurses' Health Study. Mod Pathol 2011;24:924-931.

12 Wang C, Pan B, Zhu H, Zhou Y, Mao F, Lin Y, Xu Q, Sun Q: Prognostic value of androgen receptor in triple negative breast cancer: A meta-analysis. Oncotarget 2016;7:46482-46491.

13 Soreide JA, Lea OA, Varhaug JE, Skarstein A, Kvinnsland S: Androgen receptors in operable breast cancer: relation to other steroid hormone receptors, correlations to prognostic factors and predictive value for effect of adjuvant tamoxifen treatment. Eur J Surg Oncol 1992;18:112-118.

14 Wadosky KM, Koochekpour S: Androgen receptor splice variants and prostate cancer: From bench to bedside. Oncotarget 2017;8:18632.

-15 Okuyama Kishima M, de Oliveira CE, Banin-Hirata BK, Losi-Guembarovski R, Brajao de Oliveira K, Amarante MK, Watanabe MA: Immunohistochemical expression of CXCR4 on breast cancer and its clinical significance. Anal Cell Pathol (Amst) 2015;2015:891020.

16 Luker KE, Luker GD: Functions of CXCL12 and CXCR4 in breast cancer. Cancer Lett 2006;238:30-41.

17 Hall JM, Korach KS: Stromal cell-derived factor 1, a novel target of estrogen receptor action, mediates the mitogenic effects of estradiol in ovarian and breast cancer cells. Mol Endocrinol 2003;17:792-803.

18 Pattarozzi A, Gatti M, Barbieri F, Wurth R, Porcile C, Lunardi G, Ratto A, Favoni R, Bajetto A, Ferrari A, 


\section{Cellular Physiology Cell Physiol Biochem 2017;44:66-84

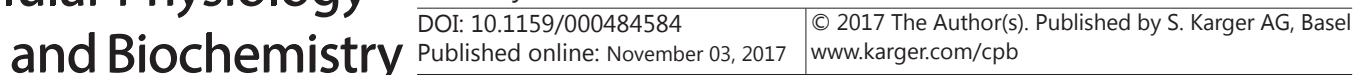

Florio T: 17beta-estradiol promotes breast cancer cell proliferation-inducing stromal cell-derived factor1-mediated epidermal growth factor receptor transactivation: reversal by gefitinib pretreatment. Mol Pharmacol 2008;73:191-202.

19 Sauve K, Lepage J, Sanchez M, Heveker N, Tremblay A: Positive feedback activation of estrogen receptors by the CXCL12-CXCR4 pathway. Cancer Res 2009;69:5793-5800.

-20 Mirisola V, Zuccarino A, Bachmeier BE, Sormani MP, Falter J, Nerlich A, Pfeffer U: CXCL12/SDF1 expression by breast cancers is an independent prognostic marker of disease-free and overall survival. Eur J Cancer 2009;45:2579-2587.

-21 Kobayashi T, Tsuda H, Moriya T, Yamasaki T, Kikuchi R, Ueda S, Omata J, Yamamoto J, Matsubara O: Expression pattern of stromal cell-derived factor-1 chemokine in invasive breast cancer is correlated with estrogen receptor status and patient prognosis. Breast Cancer Res Treat 2010;123:733-745.

-22 Boudot A, Kerdivel G, Habauzit D, Eeckhoute J, Le Dily F, Flouriot G, Samson M, Pakdel F: Differential estrogen-regulation of CXCL12 chemokine receptors, CXCR4 and CXCR7, contributes to the growth effect of estrogens in breast cancer cells. PLoS One 2011;6:e20898.

-23 Frigo DE, Sherk AB, Wittmann BM, Norris JD, Wang Q, Joseph JD, Toner AP, Brown M, McDonnell DP: Induction of Kruppel-like factor 5 expression by androgens results in increased CXCR4-dependent migration of prostate cancer cells in vitro. Mol Endocrinol 2009;23:1385-1396.

24 Kasina S, Macoska JA: The CXCL12/CXCR4 axis promotes ligand-independent activation of the androgen receptor. Mol Cell Endocrinol 2012;351:249-263.

25 Chen Y, Fu L, Han Y, Teng Y, Sun J, Xie R, Cao J: Testosterone replacement therapy promotes angiogenesis after acute myocardial infarction by enhancing expression of cytokines HIF-1a, SDF-1a and VEGF. Eur J Pharmacol 2012;684:116-124.

-26 Hsiao JJ, Ng BH, Smits MM, Wang J, Jasavala RJ, Martinez HD, Lee J, Alston JJ, Misonou H, Trimmer JS, Wright ME: Androgen receptor and chemokine receptors 4 and 7 form a signaling axis to regulate CXCL12dependent cellular motility. BMC Cancer 2015;15:204.

-27 Notas G, Pelekanou V, Castanas E, Kampa M: Conjugated and non-conjugated androgens differentially modulate specific early gene transcription in breast cancer in a cell-specific manner. Steroids 2010;75:611618.

28 Pelekanou V, Notas G, Theodoropoulou K, Kampa M, Takos D, Alexaki VI, Radojicic J, Sofras F, Tsapis A, Stathopoulos EN, Castanas E: Detection of the TNFSF members BAFF, APRIL, TWEAK and their receptors in normal kidney and renal cell carcinomas. Anal Cell Pathol (Amst) 2011;34:49-60.

-29 Notas G, Nifli AP, Kampa M, Pelekanou V, Alexaki VI, Theodoropoulos P, Vercauteren J, Castanas E: Quercetin accumulates in nuclear structures and triggers specific gene expression in epithelial cells. J Nutr Biochem 2012;23:656-666.

30 Notas G, Kampa M, Pelekanou V, Castanas E: Interplay of estrogen receptors and GPR30 for the regulation of early membrane initiated transcriptional effects: A pharmacological approach. Steroids 2012;77:943950.

-31 Baniwal SK, Little GH, Chimge NO, Frenkel B: Runx2 controls a feed-forward loop between androgen and prolactin-induced protein (PIP) in stimulating T47D cell proliferation. J Cell Physiol 2012;227:2276-2282.

-32 Liang CC, Park AY, Guan JL: In vitro scratch assay: a convenient and inexpensive method for analysis of cell migration in vitro. Nat Protoc 2007;2:329-333.

33 Leung TH, Ching YP, Yam JW, Wong CM, Yau TO, Jin DY, Ng IO: Deleted in liver cancer 2 (DLC2) suppresses cell transformation by means of inhibition of RhoA activity. Proc Natl Acad Sci U S A 2005;102:1520715212.

-34 Curtis C, Shah SP, Chin SF, Turashvili G, Rueda OM, Dunning MJ, Speed D, Lynch AG, Samarajiwa S, Yuan Y, Graf S, Ha G, Haffari G, Bashashati A, Russell R, McKinney S, Group M, Langerod A, Green A, Provenzano E, Wishart G, Pinder S, Watson P, Markowetz F, Murphy L, Ellis I, Purushotham A, Borresen-Dale AL, Brenton JD, Tavare S, Caldas C, Aparicio S: The genomic and transcriptomic architecture of 2,000 breast tumours reveals novel subgroups. Nature 2012;486:346-352.

-35 Pereira B, Chin SF, Rueda OM, Vollan HK, Provenzano E, Bardwell HA, Pugh M, Jones L, Russell R, Sammut SJ, Tsui DW, Liu B, Dawson SJ, Abraham J, Northen H, Peden JF, Mukherjee A, Turashvili G, Green AR, McKinney S, Oloumi A, Shah S, Rosenfeld N, Murphy L, Bentley DR, Ellis IO, Purushotham A, Pinder SE, Borresen-Dale AL, Earl HM, Pharoah PD, Ross MT, Aparicio S, Caldas C: The somatic mutation profiles of 2,433 breast cancers refines their genomic and transcriptomic landscapes. Nat Commun 2016;7:11479. 


\section{Cellular Physiology Cell Physiol Biochem 2017;44:66-84 \begin{tabular}{l|l} 
and Biochemistry Publ: 10.1159/000484584 & $\begin{array}{l}\text { (c) } 2017 \text { The Author(s). Published by S. Karger AG, Basel } \\
\text { www.karger.com/cpb }\end{array}$
\end{tabular}

-36 Gao J, Aksoy BA, Dogrusoz U, Dresdner G, Gross B, Sumer SO, Sun Y, Jacobsen A, Sinha R, Larsson E, Cerami E, Sander C, Schultz N: Integrative analysis of complex cancer genomics and clinical profiles using the cBioPortal. Sci Signal 2013;6:pl1.

-37 Cerami E, Gao J, Dogrusoz U, Gross BE, Sumer SO, Aksoy BA, Jacobsen A, Byrne CJ, Heuer ML, Larsson E, Antipin Y, Reva B, Goldberg AP, Sander C, Schultz N: The cBio cancer genomics portal: an open platform for exploring multidimensional cancer genomics data. Cancer Discov 2012;2:401-404.

-38 Zhu Y, Xu Y, Helseth DL, Jr., Gulukota K, Yang S, Pesce LL, Mitra R, Muller P, Sengupta S, Guo W, Silverstein JC, Foster I, Parsad N, White KP, Ji Y: Zodiac: A Comprehensive Depiction of Genetic Interactions in Cancer by Integrating TCGA Data. J Natl Cancer Inst 2015;107:

39 Zhu Y, Qiu P, Ji Y: TCGA-assembler: open-source software for retrieving and processing TCGA data. Nat Methods 2014;11:599-600.

40 Miller WR, Larionov AA, Renshaw L, Anderson TJ, White S, Murray J, Murray E, Hampton G, Walker JR, Ho S, Krause A, Evans DB, Dixon JM: Changes in breast cancer transcriptional profiles after treatment with the aromatase inhibitor, letrozole. Pharmacogenet Genomics 2007;17:813-826.

41 Susa T, Ikaga R, Kajitani T, Iizuka M, Okinaga H, Tamamori-Adachi M, Okazaki T: Wild-type and specific mutant androgen receptor mediates transcription via 17beta-estradiol in sex hormone-sensitive cancer cells. J Cell Physiol 2015;230:1594-1606.

-42 Garay JP, Karakas B, Abukhdeir AM, Cosgrove DP, Gustin JP, Higgins MJ, Konishi H, Konishi Y, Lauring J, Mohseni M, Wang GM, Jelovac D, Weeraratna A, Sherman Baust CA, Morin PJ, Toubaji A, Meeker A, De Marzo AM, Lewis G, Subhawong A, Argani P, Park BH: The growth response to androgen receptor signaling in ERalpha-negative human breast cells is dependent on p21 and mediated by MAPK activation. Breast Cancer Res 2012;14:R27.

-43 Lu S, Jenster G, Epner DE: Androgen induction of cyclin-dependent kinase inhibitor p21 gene: role of androgen receptor and transcription factor Sp1 complex. Mol Endocrinol 2000;14:753-760.

-44 Ou XM, Chen K, Shih JC: Glucocorticoid and androgen activation of monoamine oxidase A is regulated differently by R1 and Sp1. J Biol Chem 2006;281:21512-21525.

-45 Darne CH, Morel L, Claessens F, Manin M, Fabre S, Veyssiere G, Rombauts W, Jean CL: Ubiquitous transcription factors NF1 and Sp1 are involved in the androgen activation of the mouse vas deferens protein promoter. Mol Cell Endocrinol 1997;132:13-23.

46 Dasgupta S, Lonard DM, O'Malley BW: Nuclear receptor coactivators: master regulators of human health and disease. Annu Rev Med 2014;65:279-292.

47 Foley C, Mitsiades N: Moving Beyond the Androgen Receptor (AR): Targeting AR-Interacting Proteins to Treat Prostate Cancer. Horm Cancer 2016;7:84-103.

48 Kishimoto H, Wang Z, Bhat-Nakshatri P, Chang D, Clarke R, Nakshatri H: The p160 family coactivators regulate breast cancer cell proliferation and invasion through autocrine/paracrine activity of SDF-1alpha/ CXCL12. Carcinogenesis 2005;26:1706-1715.

49 Kampa M, Pelekanou V, Gallo D, Notas G, Troullinaki M, Pediaditakis I, Charalampopoulos I, Jacquot Y, Leclercq G, Castanas E: ERalpha17p, an ERalpha P295 -T311 fragment, modifies the migration of breast cancer cells, through actin cytoskeleton rearrangements. J Cell Biochem 2011;112:3786-3796.

$\rightarrow 50$ Mehta SA, Christopherson KW, Bhat-Nakshatri P, Goulet RJ, Jr., Broxmeyer HE, Kopelovich L, Nakshatri $\mathrm{H}$ : Negative regulation of chemokine receptor CXCR4 by tumor suppressor p53 in breast cancer cells: implications of p53 mutation or isoform expression on breast cancer cell invasion. Oncogene 2007;26:3329-3337.

51 Coradini D, Fornili M, Ambrogi F, Boracchi P, Biganzoli E: TP53 mutation, epithelial-mesenchymal transition, and stemlike features in breast cancer subtypes. J Biomed Biotechnol 2012;2012:254085.

-52 O‘Connor PM, Jackman J, Bae I, Myers TG, Fan S, Mutoh M, Scudiero DA, Monks A, Sausville EA, Weinstein JN, Friend S, Fornace AJ, Jr., Kohn KW: Characterization of the p53 tumor suppressor pathway in cell lines of the National Cancer Institute anticancer drug screen and correlations with the growth-inhibitory potency of 123 anticancer agents. Cancer Res 1997;57:4285-4300.

53 Polotskaia A, Xiao G, Reynoso K, Martin C, Qiu WG, Hendrickson RC, Bargonetti J: Proteome-wide analysis of mutant p53 targets in breast cancer identifies new levels of gain-of-function that influence PARP, PCNA, and MCM4. Proc Natl Acad Sci U S A 2015;112:E1220-1229.

54 Ryerson AB, Eheman CR, Altekruse SF, Ward JW, Jemal A, Sherman RL, Henley SJ, Holtzman D, Lake A, Noone AM, Anderson RN, Ma J, Ly KN, Cronin KA, Penberthy L, Kohler BA: Annual Report to the Nation on 


\section{Cellular Physiology Cell Physiol Biochem 2017;44:66-84 \begin{tabular}{l|l} 
and Biochemistry Published online: November 03, 2017 & $\begin{array}{l}\text { (c) } 2017 \text { The Author(s). Published by S. Karger AG, Basel } \\
\text { www.karger.com/cpb }\end{array}$
\end{tabular} \\ Azariadis et al.: Androgen Induce CXCL12 in AR-Positive Breast Cancer}

the Status of Cancer, 1975-2012, featuring the increasing incidence of liver cancer. Cancer 2016;122:13121337.

55 Zhu A, Li Y, Song W, Xu Y, Yang F, Zhang W, Yin Y, Guan X: Antiproliferative Effect of Androgen Receptor Inhibition in Mesenchymal Stem-Like Triple-Negative Breast Cancer. Cell Physiol Biochem 2016;38:10031014.

56 McBryan J, Theissen SM, Byrne C, Hughes E, Cocchiglia S, Sande S, O‘Hara J, Tibbitts P, Hill AD, Young LS: Metastatic progression with resistance to aromatase inhibitors is driven by the steroid receptor coactivator SRC-1. Cancer Res 2012;72:548-559.

-57 Lim LY, Vidnovic N, Ellisen LW, Leong CO: Mutant p53 mediates survival of breast cancer cells. Br J Cancer 2009;101:1606-1612.

58 Shufelt CL, Braunstein GD: Testosterone and the breast. Menopause Int 2008;14:117-122.

\$59 Birrell SN, Bentel JM, Hickey TE, Ricciardelli C, Weger MA, Horsfall DJ, Tilley WD: Androgens induce divergent proliferative responses in human breast cancer cell lines. J Steroid Biochem Mol Biol 1995;52:459-467.

60 Ando S, De Amicis F, Rago V, Carpino A, Maggiolini M, Panno ML, Lanzino M: Breast cancer: from estrogen to androgen receptor. Mol Cell Endocrinol 2002;193:121-128.

61 Pelekanou V, Notas G, Stathopoulos EN, Castanas E, Kampa M: Androgen receptors in early and castration resistant prostate cancer: friend or foe? Hormones (Athens) 2013;12:224-235.

62 Pelekanou V, Notas G, Sanidas E, Tsapis A, Castanas E, Kampa M: Testosterone membrane-initiated action in breast cancer cells: Interaction with the androgen signaling pathway and EPOR. Mol Oncol 2010;4:135149.

63 Chia K, O`Brien M, Brown M, Lim E: Targeting the androgen receptor in breast cancer. Curr Oncol Rep 2015;17:4.

-64 Vera-Badillo FE, Templeton AJ, de Gouveia P, Diaz-Padilla I, Bedard PL, Al-Mubarak M, Seruga B, Tannock IF, Ocana A, Amir E: Androgen receptor expression and outcomes in early breast cancer: a systematic review and meta-analysis. J Natl Cancer Inst 2014;106:djt319.

65 Rechoum Y, Rovito D, Iacopetta D, Barone I, Ando S, Weigel NL, O’Malley BW, Brown PH, Fuqua SA: AR collaborates with ERalpha in aromatase inhibitor-resistant breast cancer. Breast Cancer Res Treat 2014;147:473-485.

66 Park S, Koo JS, Kim MS, Park HS, Lee JS, Lee JS, Kim SI, Park BW, Lee KS: Androgen receptor expression is significantly associated with better outcomes in estrogen receptor-positive breast cancers. Ann Oncol 2011;22:1755-1762.

67 Goldenberg IS: Testosterone Propionate Therapy in Breast Cancer. JAMA 1964;188:1069-1072.

68 Tormey DC, Lippman ME, Edwards BK, Cassidy JG: Evaluation of tamoxifen doses with and without fluoxymesterone in advanced breast cancer. Ann Intern Med 1983;98:139-144.

-69 Boni C, Pagano M, Panebianco M, Bologna A, Sierra NM, Gnoni R, Formisano D, Bisagni G: Therapeutic activity of testoterone in metastatic breast cancer. Anticancer Res 2014;34:1287-1290.

70 Gallicchio L, Macdonald R, Wood B, Rushovich E, Helzlsouer KJ: Androgens and musculoskeletal symptoms among breast cancer patients on aromatase inhibitor therapy. Breast Cancer Res Treat 2011;130:569-577.

-71 Harvell DM, Richer JK, Singh M, Spoelstra N, Finlayson C, Borges VF, Elias AD, Horwitz KB: Estrogen regulated gene expression in response to neoadjuvant endocrine therapy of breast cancers: tamoxifen agonist effects dominate in the presence of an aromatase inhibitor. Breast Cancer Res Treat 2008;112:489501.

-72 Harvell DM, Spoelstra NS, Singh M, McManaman JL, Finlayson C, Phang T, Trapp S, Hunter L, Dye WW, Borges VF, Elias A, Horwitz KB, Richer JK: Molecular signatures of neoadjuvant endocrine therapy for breast cancer: characteristics of response or intrinsic resistance. Breast Cancer Res Treat 2008;112:475488.

73 De Amicis F, Thirugnansampanthan J, Cui Y, Selever J, Beyer A, Parra I, Weigel NL, Herynk MH, Tsimelzon A, Lewis MT, Chamness GC, Hilsenbeck SG, Ando S, Fuqua SA: Androgen receptor overexpression induces tamoxifen resistance in human breast cancer cells. Breast Cancer Res Treat 2010;121:1-11.

74 D‘Amato NC, Gordon MA, Babbs B, Spoelstra NS, Carson Butterfield KT, Torkko KC, Phan VT, Barton VN, Rogers TJ, Sartorius CA, Elias A, Gertz J, Jacobsen BM, Richer JK: Cooperative Dynamics of AR and ER Activity in Breast Cancer. Mol Cancer Res 2016;14:1054-1067. 